\title{
Cirsium japonicum extract induces apoptosis and anti- proliferation in the human breast cancer cell line MCF-7
}

\author{
DO-YEON KIM, SUNG-HAK KANG and SUNG-HO GHIL \\ Department of Life Science, Kyonggi University, Suwon 443-760, Korea
}

Received November 9, 2009; Accepted February 19, 2010

DOI: 10.3892/mmr_00000275

\begin{abstract}
Cirsium japonicum is a wild perennial herb that has been used as an anti-hemorrhagic, anti-hypertensive and uretic agent in traditional Chinese medicine. Recently, it was reported that $C$. japonicum inhibits the growth of implanted cancer cells. However, the molecular mechanisms underlying the anti-cancer properties of $C$. japonicum are not fully understood. In this study, we investigated the effect of a methanol extract of $C$. japonicum on cell growth in the human breast cancer cell line MCF-7. C. japonicum extract inhibited the cell proliferation of MCF-7 cells in a time- and dose-dependent manner, as evaluated by the MTT assay. Furthermore, C. japonicum extract induced an antiproliferative effect by causing $G_{1}$ phase cell cycle arrest and also induced apoptosis by affecting mitochondrial apoptotic events, as determined by nuclear derangement, flow cytometry and Western blot analysis. Taken together, our findings indicate that $C$. japonicum extract induces the inhibition of MCF-7 cell growth at both the proliferation and apoptosis levels.
\end{abstract}

\section{Introduction}

Currently, many efforts are underway to develop new therapeutic anti-cancer drugs from natural sources. A major natural reservoir is plant material. Plant secondary metabolites have occasionally been used as chemotherapeutic agents to mediate cytostatic activity in cancer cells. Widely used anti-mitotic anti-cancer drugs including Vinca alkaloids and paclitaxel have been isolated from Catharanthus roseus and Taxus baccata, respectively (1). The DNA polymerase I inhibitor camptothecin was sourced from Camptotheca acuminata (2). Curcumin isolated from Curcuma longa has shown anticancer properties, such as the inhibition of tumor promotion and the induction of apoptosis in cancer cells (3-5).

Correspondence to: Dr Sung-Ho Ghil, Department of Life Science, Kyonggi University, Suwon 443-760, Korea

E-mail: shghil@kgu.ac.kr

Key words: anti-proliferation, apoptosis, cell cycle, Cirsium japonicum, human breast cancer
Cirsium japonicum is a wild perennial herb found in many areas of Korea, Japan and China. It has been used as an anti-hemorrhagic, anti-hypertensive and uretic agent in traditional Chinese medicine (6). Recent studies have found that the water extracts of $C$. japonicum induce the activation of estrogen receptors and have estrogenic effects (7). C. japonicum also contains a vasorelaxant principle, mediating histamine H1-receptor activation (8). In traditional medicine, C. japonicum has sometimes been used for the management of different types of cancer, including liver and uterine cancer and leukemia (9).

Recently, it was reported that $C$. japonicum and its flavone components induce the inhibition of tumor formation in mice $(9,10)$. However, the mechanism underlying the anti-cancer effects of these $C$. japonicum compounds are not fully understood.

In the present study, we observed that a methanol extract of $C$. japonicum significantly reduced cancer cell growth in a time- and dose-dependent manner, using the human breast cancer cell line MCF-7. Furthermore, we investigated the molecular mechanisms underlying the anti-proliferative activities of $C$. japonicum.

\section{Materials and methods}

Preparation of $C$. japonicum extract. Dried roots of C.japonicum from Korea were purchased from the Kyungdong oriental medicine market in Seoul, Korea. C. japonicum material (100 g) was extracted with $99.8 \%$ methanol (1 liter) for $72 \mathrm{~h}$ at room temperature. The extract was evaporated to dryness on a rotary evaporator and dissolved in dimethylsulfoxide (DMSO; Sigma-Aldrich, St. Louis, MO).

Cell culture. The human breast cancer cell line MCF-7 was maintained in Dulbecco's modified Eagle's medium, supplemented with $10 \%$ fetal bovine serum, $100 \mathrm{U} / \mathrm{ml}$ penicillin and $100 \mu \mathrm{g} / \mathrm{ml}$ streptomycin (all from Hyclone, South Logan, UT) at $37^{\circ} \mathrm{C}$ in a humidified incubator under $5 \% \mathrm{CO}_{2}$.

Cell proliferation assay. The effect of $C$. japonicum extract on MCF-7 cell proliferation was measured using the 3-(4,5dimethyl-2-thiazolyl)-2,5-diphenyl-2H-tetrazolium bromide (MTT) assay, which is based on the ability of live cells to cleave the tetrazolium ring to a molecule that absorbs at $570 \mathrm{~nm}$. Cells ( $3 \times 10^{3} /$ well) were plated on 96 -well microplates. 
Twenty-four hours later, the cells were incubated with various concentrations of $C$. japonicum extract $(0-100 \mu \mathrm{g} / \mathrm{ml})$ for the indicated time. After incubation, $10 \mu \mathrm{l} \mathrm{MTT}$ solution $(5 \mathrm{mg} /$ ml) (Sigma) was added to each well, and cells were further incubated at $37^{\circ} \mathrm{C}$. After $4 \mathrm{~h}$ of incubation, $100 \mu \mathrm{l}$ of isopropyl alcohol dissolved in $5 \% 1 \mathrm{~N} \mathrm{HCl}$ was added to solubilize the formazan crystals. Absorbance was measured using a SpectraMax Plus 384 microplate reader (Molecular Devices, Sunnyvale, CA). Cells were never exposed to $>0.5 \%$ DMSO concentrations.

Analysis of nuclear morphology. MCF-7 cells were plated on coverslips at a density of $5 \times 10^{3}$ cells/coverslip and exposed to C. japonicum extract at $30 \mu \mathrm{g} / \mathrm{ml}$. After $72 \mathrm{~h}$ of incubation, the cells were fixed in $4 \%$ paraformaldehyde for $10 \mathrm{~min}$, and nuclei were stained with $10 \mu \mathrm{g} / \mathrm{ml}$ Hoechst 33258 (Sigma) for 20 min. Nuclear morphology was observed by fluorescence microscopy (BX-50; Olympus, Tokyo, Japan).

DNA ladder formation assay. MCF-7 cells ( $2 \times 10^{5}$ cells/dish) were plated on 100-mm tissue culture dishes. The cells were treated with $100 \mu \mathrm{g} / \mathrm{ml} \mathrm{C}$. japonicum extract and incubated for the indicated times, then washed with PBS and lysed with the AccuPrep ${ }^{\circledR}$ Genomic DNA Extraction kit (Bioneer, Daejeon, Korea) as recommended by the manufacturer. DNA concentration was measured using a BioPhotometer (Eppendorf, Hamburg, Germany), then the DNA was separated on $1.5 \%$ agarose gels and visualized by ethidium bromide staining.

Cell cycle and Annexin-V/propidium iodide flow cytometric analysis. MCF-7 cells $\left(2 \times 10^{5}\right.$ cells/dish) were plated on 100-mm tissue culture dishes. Cells were treated with $70 \mu \mathrm{g} /$ $\mathrm{ml} C$. japonicum extract for the indicated times. Cells were harvested by trypsinization, washed with ice-cold PBS and fixed in $70 \%$ ethanol for $20 \mathrm{~min}$. For cell cycle analysis, fixed cells were stained with propidium iodide (PI) solution (PBS containing $50 \mu \mathrm{g} / \mathrm{ml} \mathrm{PI}, 10 \mu \mathrm{g} / \mathrm{ml}$ RNase A and $3.8 \mathrm{mM}$ sodium citrate) at $4^{\circ} \mathrm{C}$ for $20 \mathrm{~min}$. For Annexin-V/PI flow cytometric analysis, fixed cells were stained using the FITC Annexin-V Apoptosis Detection kit I (BD Biosciences, San Diego, CA) as recommended by the manufacturer. Flow cytometric analysis used a FACSVantage SE (Becton-Dickinson, San Jose, CA). Data from 10,000 cells per sample were collected and analyzed.

Western blot analysis. MCF-7 cells ( $2 \times 10^{5}$ cells/dish) were plated on 100-mm tissue culture dishes. Cells were treated with $50 \mu \mathrm{g} / \mathrm{ml}$ of $C$. japonicum extract for the indicated times, then rinsed twice with ice-cold PBS, harvested and extracted with PBTX buffer (PBS containing $5 \mathrm{mM} \mathrm{MgCl}_{2}, 1 \mathrm{mM}$ EDTA and $0.1 \%$ Triton X-100) containing protease inhibitors (5 $\mu \mathrm{g} / \mathrm{ml}$ aprotinin, $10 \mu \mathrm{g} / \mathrm{ml}$ leupeptin, $2 \mu \mathrm{g} / \mathrm{ml}$ pepstatin A and $2 \mathrm{mM}$ phenylmethylsulfonyl fluoride). Cell lysates were centrifuged at $12,000 \mathrm{rpm}$ for $10 \mathrm{~min}$ at $4^{\circ} \mathrm{C}$. Protein $(50 \mu \mathrm{g})$ was subjected to $8-12 \%$ SDS-PAGE before electrotransfer to a PVDF membrane (Westran S; Whatman, Florham Park, NJ). Blots were blocked in 5\% non-fat dry milk for $1 \mathrm{~h}$ at room temperature and incubated with antibodies against p53, Bax, Bcl-2, cyclin-dependent protein kinase $4(\mathrm{cdk} 4)$, cyclin D1, E2F1, poly (ADP-ribose) polymerase (PARP)-1/2, caspase-7

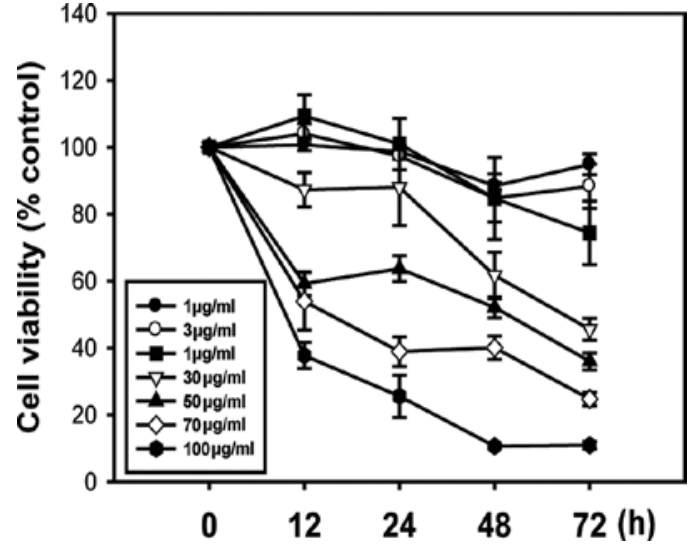

Figure 1. Effect of C. japonicum extract on the proliferation of MCF-7 cells. Cells were treated with a methanol extract of $C$. japonicum for various times and at different concentrations. Cell proliferation was measured using the MTT assay. Each point represents the mean of data from three independent experiments.

(all at 1:500 dilution) (all from Santa Cruz Biotechnology, Santa Cruz, CA), or $\alpha$-tubulin (1:2,500 dilution) (Upstate Biotechnology, Temecula, CA). Membranes were then incubated with the corresponding secondary antibodies, either goat anti-mouse IgG HRP conjugate (1:5,000 dilution) (Zymed, Carlsbad, CA) or goat anti-rabbit IgG HRP conjugate (1:25,000 dilution) (Zymed). Transferred proteins were visualized using an enhanced chemiluminescence detection kit (West-Zol ${ }^{\circledR}$; Intron Biotechnology, Sungnam, Korea).

\section{Results}

Effect of $C$. japonicum extract on the proliferation of the human breast cancer cell line MCF-7. To investigate the effects of $C$. japonicum extract on MCF-7 proliferation, we exposed cells to $0-100 \mu \mathrm{g} / \mathrm{ml}$ of $C$. japonicum extract for the indicated times and measured cell proliferation using the MTT assay. As shown in Fig. 1, C. japonicum extract significantly inhibited the proliferation of MCF-7 cells in a time- and dosedependent manner. The median effective doses ( $\mathrm{EC}_{50}$ values) of $C$. japonicum extract were $78.7 \pm 8.8,73.6 \pm 11.3,51.8 \pm 10.0$ and $44.2 \pm 12.1 \mu \mathrm{g} / \mathrm{ml}$ at $12,24,48$ and $72 \mathrm{~h}$, respectively.

Apoptotic activity of C. japonicum extract acting on MCF-7 cells. To determine whether $C$. japonicum extract causes the apoptotic cell death of MCF-7 cells, we treated the cells with the extract at $30 \mu \mathrm{g} / \mathrm{ml}$ for $72 \mathrm{~h}$, then stained them with Hoechst 33258. As shown in Fig. 2A, condensed chromatin was observed by fluorescence microscopy in the test cells, but not in the controls. Furthermore, agarose gel electrophoresis of DNA from cells treated with $C$. japonicum extract showed a ladder-like pattern of DNA fragments. The apoptosisinducing activity of the extract was time-dependent (Fig. 2B). To confirm the apoptosis-promoting potential of $C$. japonicum extract, we treated the cells with the extract at $70 \mu \mathrm{g} / \mathrm{ml}$ for the indicated times and performed flow cytometry after Annexin-V/PI dual staining. The dot plots show non-apoptotic live cells in the lower left quadrant (Annexin-V-/PI'), apoptotic cells in the lower right quadrant (Annexin- $\mathrm{V}^{+} / \mathrm{PI}$ ) and cells in late apoptosis or necrosis in the upper right quadrant 
A
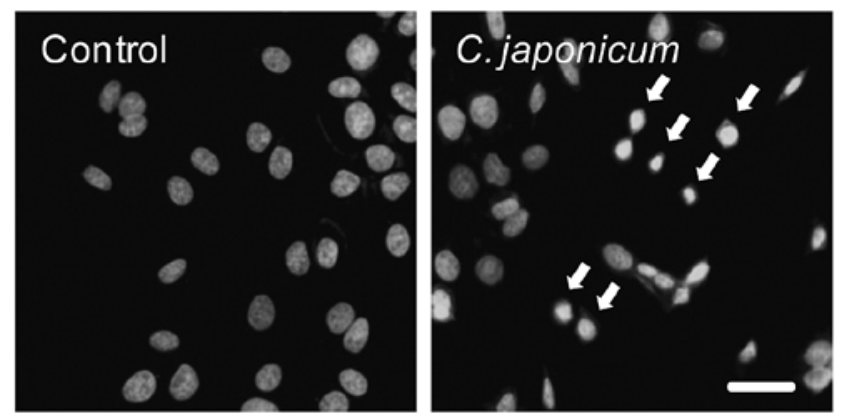

B

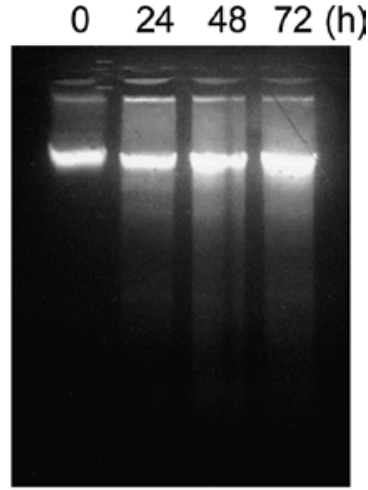

C
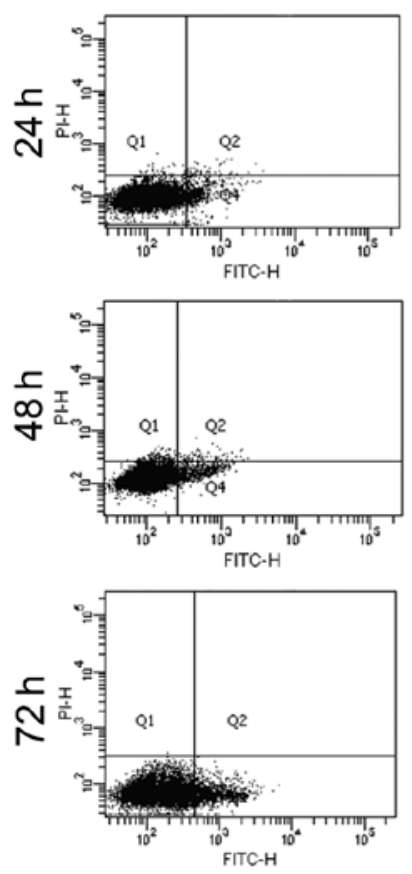

C. japonicum
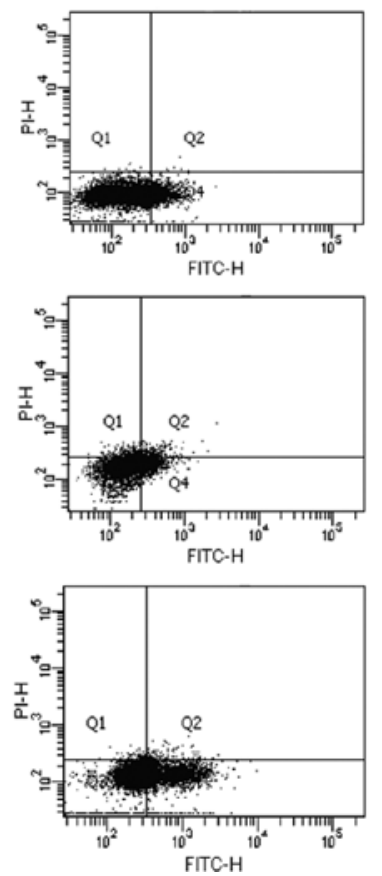

D

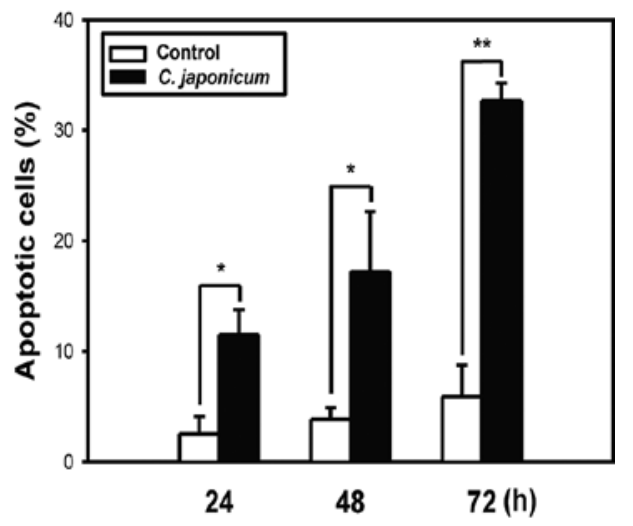

Figure 2. Apoptotic activity of $C$. japonicum extract acting on MCF-7 cells. (A) Cells were incubated with or without $30 \mu \mathrm{g} / \mathrm{ml}$ extract for $72 \mathrm{~h}$ and stained with Hoechst 33258 dye. Arrows indicate condensed chromatin in cell nuclei. Scale bar, $50 \mu \mathrm{m}$. (B) Cells were incubated with $100 \mu \mathrm{g} / \mathrm{ml} C$. japonicum extract for the indicated times followed by the DNA ladder formation assay. (C) MCF-7 cells were incubated with or without $70 \mu \mathrm{g} / \mathrm{ml} C$. japonicum extract for the indicated times, stained with Annexin-V/PI and analyzed by flow cytometry. (D) The percentages of apoptotic cells (Annexin- $\mathrm{V}^{+} / \mathrm{PI}{ }^{-}$cells) are shown. Data are the means \pm SE of three independent experiments. ${ }^{*} \mathrm{P}<0.05 ;{ }^{* *} \mathrm{P}<0.01$.

(Annexin- $\left.\mathrm{V}^{+} / \mathrm{PI}^{+}\right)$. The addition of $C$. japonicum extract significantly increased the proportion of apoptotic cells at all time points (Fig. 2C and D). These results indicate that C. japonicum extract potentiated the apoptotic death of MCF-7 cells.

Effect of $C$. japonicum extract on cell cycle progression. To investigate the basis for the anti-proliferative properties of $C$. japonicum extract, MCF-7 cells were treated with the extract at $30 \mu \mathrm{g} / \mathrm{ml}$ for the indicated times, stained with PI and analyzed by flow cytometry. Incubation with $C$. japonicum extract significantly increased the proportions of cells in the sub- $\mathrm{G}_{1}$ and $\mathrm{G}_{1}$ phases at all time points, compared with the control cells (Fig. 3A and B). The number of cells in the $\mathrm{G}_{2} / \mathrm{M}$ and $\mathrm{S}$ phases decreased or was similar to the levels noted in the controls (Fig. 3C and D). These results indicated that $C$. japonicum extract induced both apoptotic cell death and cell cycle arrest in the $\mathrm{G}_{1}$ phase in MCF-7 cells.
Effect of $C$. japonicum extract on the expression of cell cycle-and apoptosis-related proteins. Western blot analysis was used to determine the expression levels of cell cycle- and apoptosis-related proteins. The levels of the $G_{1}$ phase cell cycle regulatory proteins, including cyclin D1, cdk4 and the transcription factor E2F1, significantly decreased in a timedependent manner after exposure of the cells to the extract (Fig. 4A and B). The tumor suppressor gene p53 mediates either cell cycle arrest or apoptosis in response to DNA damage (11-13). Treatment with $50 \mu \mathrm{g} / \mathrm{ml}$ C. japonicum extract increased expression of p53 (Fig. 4C and D). Bcl-2 and Bax protein levels were also measured in cultured MCF-7 cells to investigate the involvement of these proteins in $C$. japonicum extract-mediated apoptosis. As shown in Fig. 4C, cells treated with $C$. japonicum extract showed an increase in Bax expression and a decrease in Bcl-2 in a time-dependent manner. Densitometry was used to determine $\mathrm{Bax} / \mathrm{Bcl}-2$ ratios. The ratio was significantly increased in a time-dependent 
A

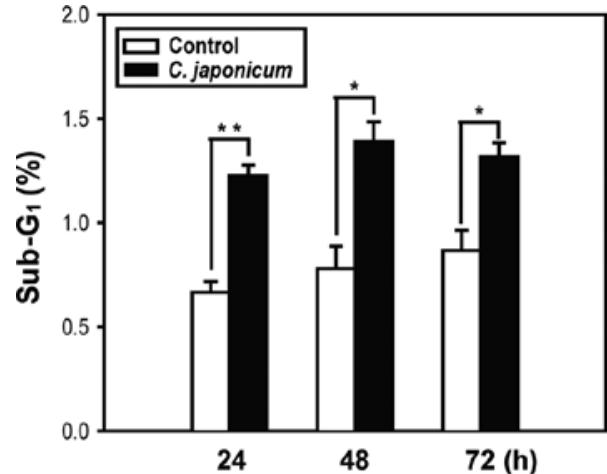

C

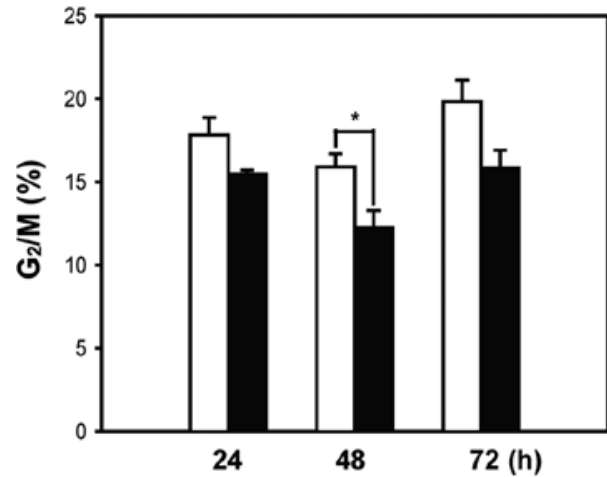

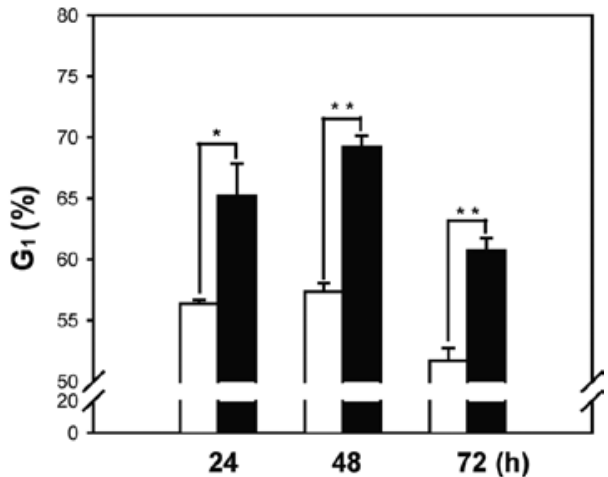

D

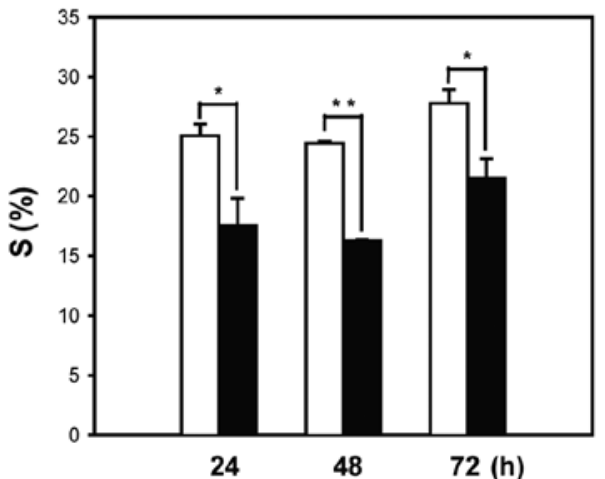

Figure 3. Effect of $C$. japonicum extract on cell cycle progression in MCF-7 cells. Cells were incubated with $70 \mu \mathrm{g} / \mathrm{ml}$ of $C$. japonicum extract for the indicated times, stained with PI and analyzed by flow cytometry. $G_{1}(B), G_{2} / M(C)$ and $S$ (D) indicate the cell cycle phase, and sub- $G_{1}(A)$ DNA content refers to the proportion of apoptotic cells. Data are the means $\pm \mathrm{SE}$ of three independent experiments. ${ }^{*} \mathrm{P}<0.05 ;{ }^{* *} \mathrm{P}<0.01$.

manner after treatment with the extract (Fig. 4E). The final activators of apoptosis are the caspases, a family of cysteine proteases that are activated by mitochondrial cytochrome $c$ release $(14,15)$. Our Western blotting results indicated that the specific immunoreactive band intensity of procaspases-7 decreased in the cells treated with $C$. japonicum extract in a time-dependent manner (Fig. 4C and D). Additional evidence of caspase activation was provided by the cleavage of PARP, as shown by Western blot analysis. The incubation of MCF-7 cells with extract resulted in the formation of $85-\mathrm{kDa}$ protein fragments in a time-dependent manner (Fig. 4C and D).

\section{Discussion}

In the present study, $C$. japonicum extract potently inhibited the proliferation of MCF-7 cells in a time- and dose-dependent manner (Fig. 1). Treatment with the $C$. japonicum extract induced nuclear derangement such as nuclear condensation and DNA ladder formation, caused an increase in the Annexin- $\mathrm{V}^{+} / \mathrm{PI}-$ cell population and resulted in cell accumulation in the sub- $\mathrm{G}_{1}$ phase, indicating that $C$. japonicum extract induces apoptotic cell death in MCF-7 cells (Figs. 2 and 3). Morphological changes such as condensed and fragmented chromatin are associated with apoptotic cell death. An increase in Annexin- $V$ reactivity and sub- $G_{1}$ phase cell accumulation are also usually considered to reflect an apoptotic cell death profile (16).

To determine the precise mechanism of $C$. japonicum extract-induced apoptotic cell death in MCF-7 cells, we examined the expression of apoptosis-related proteins by Western blot analysis. Bcl-2 family proteins regulate the progression of cells to apoptosis via activation of the caspase cascade (17). Increased expression of pro-apoptotic proteins (such as Bax and Bak) and decreased levels of anti-apoptotic proteins (such as Bcl-2 and Bcl-xL) activate the mitochondrial release of pro-apoptotic molecules, including cytochrome $c$ and apoptosis-inducing factor, into the cytosol (18-20). It has been reported that an increase in the $\mathrm{Bax} / \mathrm{Bcl}-2$ ratio triggers mitochondria-mediated cell death in MCF-7 cells $(21,22)$. Cytochrome $c$ released from mitochondria induces the conversion of procaspases to caspases $(17,23,24)$. Activated caspases cause the cleavage of various cellular substrates, and induce the morphological and biochemical characteristics of apoptosis, including cell shrinkage, DNA fragmentation, chromatin condensation and membrane blebbing $(19,25)$. Activated caspases-3 and -7 cleave PARP, a nuclear protein involved in the maintenance of DNA stability, the modification of many nuclear proteins and post-translational modification, thus triggering apoptosis (26). Caspase-3, however, is not expressed in MCF-7 cells (27). In the present study, increases in the Bax/Bcl-2 ratio, decreases in the level of procaspase-7, and PARP cleavage resulting from treatment with an extract of $C$. japonicum all indicate the involvement of mitochondrial events in the apoptosis of MCF-7 cells.

The growth of normal cells is regulated by a balance between cell proliferation and apoptosis. One of the characteristics of cancer cells is the derangement of this control system (28). In the present study, C. japonicum extract not only 
A

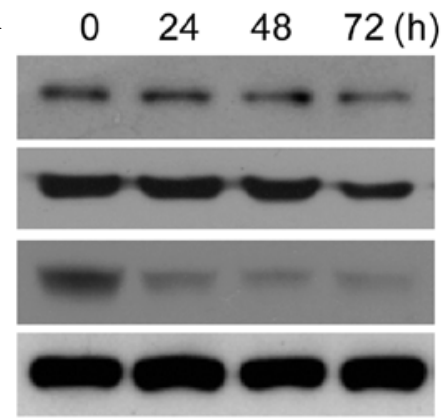

cdk4

cyclin D1

E2F1

$\alpha$-tubulin

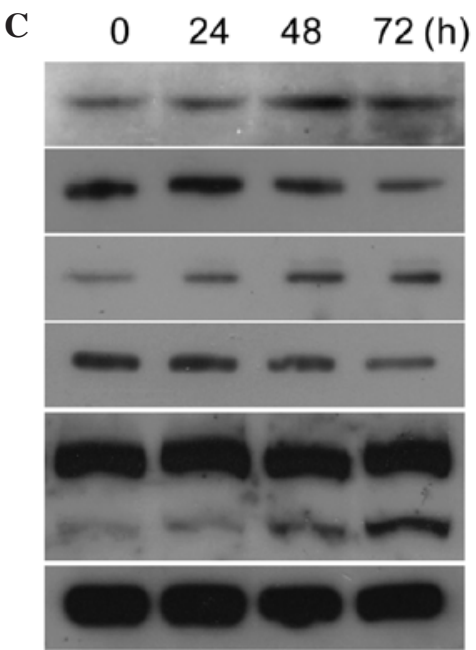

p53

$\mathrm{Bcl}-2$

Bax

procaspase-7

PARP

cleaved PARP $\alpha$-tubulin

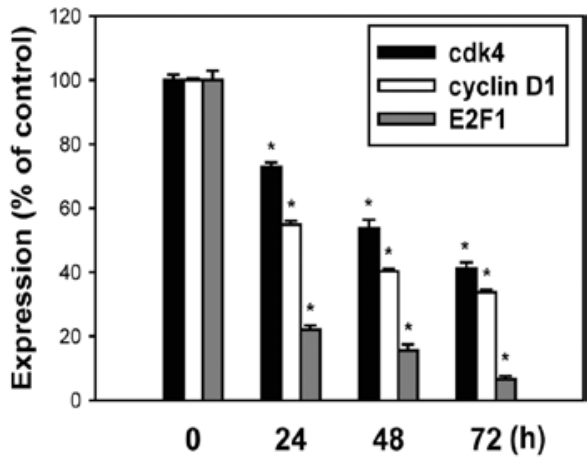

D

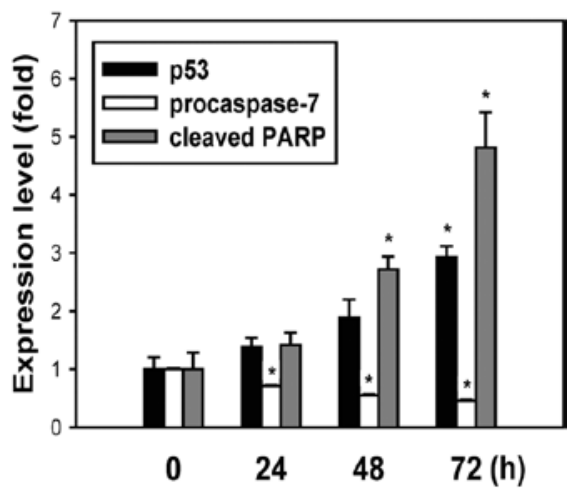

$\mathbf{E}$

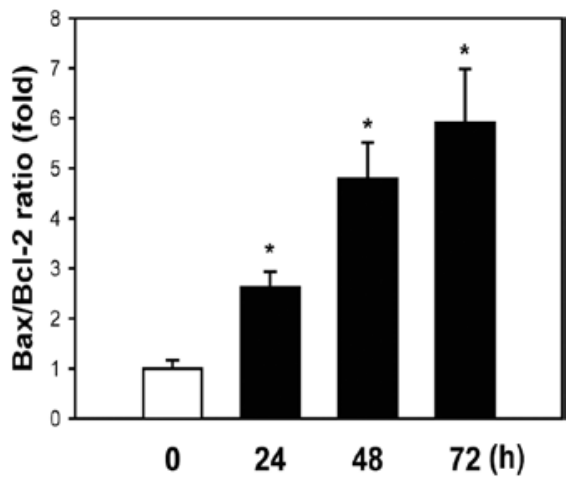

Figure 4. Effects of $C$. japonicum extract on cell cycle- and apoptosis-related protein expression. MCF-7 cells were treated with $50 \mu \mathrm{g} / \mathrm{ml} C$. japonicum extract for the indicated times and subjected to Western blot analysis. (A) Expression levels of cell cycle-related proteins were measured by using antibodies against cdk4, cyclin D1 and E2F1. $\alpha$-tubulin was used as an internal control. (B and D) Relative band intensities of each protein were quantified by densitometry. (C) Expression levels of apoptosis-related proteins were measured by using antibodies against p53, Bax, Bcl-2, caspase-7 and PARP. (E) The Bax/Bcl-2 ratios are shown. Data are the means $\pm \mathrm{SE}$ of three independent experiments. ${ }^{*} \mathrm{P}<0.01$, with respect to the corresponding control.

induced apoptosis, but repressed proliferation, thereby leading to the significant accumulation of cells in the $G_{1}$ phase. As shown in Fig. 3, after a 48-h incubation with MCF-7 cells, the extract increased the cell population in the $G_{1}$ phase from 57.4 to $69.2 \%$. Our data clearly show that this substantial increase in the proportion of cells in the $G_{1}$ phase was accompanied by a decrease in cells in the $G_{2} / M$ and $S$ phases at this time point.

The cell cycle is regulated by cyclin and cdk complexes (29). In the $\mathrm{G}_{1}$ phase, cyclinD/cdk4 or cdk6 phosphorylate retinoblastoma protein $(\mathrm{pRb})$, resulting in the inactivation of $\mathrm{pRb}$. This in turn allows for the expression of the E2F1 transcription factor, which controls the gene expression necessary for cell cycle progression $(30,31)$. As shown in Fig. 4, treatment with $C$. japonicum extract significantly down-regulated the expression of cdk4, cyclin D1 and E2F1 in a time-dependent manner, suggesting a possible explanation for the $G_{1}$ phase cell cycle arrest noted here.

In conclusion, we present a possible mechanism by which $C$. japonicum extract induces apoptosis as well as anti-proliferative activity in the human breast cancer cell line MCF-7. C. japonicum extract induces apoptosis by affecting mitochondrial apoptotic events such as the increase in Bax/ Bcl-2 ratio, caspase activity and PARP cleavage. $C$. japonicum extract also exerts an anti-proliferative effect through the down-regulation of cdk4, cyclin D1 and E2F1, which leads to cell cycle arrest in the $\mathrm{G}_{1}$ phase. If these anti-tumor effects are supported by additional in vivo experiments, it may be possible to use $C$. japonicum to mediate chemotherapeutic and cytostatic activity in human breast cancer. 


\section{Acknowledgements}

This study was supported by a Korea Research Foundation Grant funded by the Korean Government (MOEHRD, Basic Research Promotion fund) (KRF-2007-331-C00202).

\section{References}

1. Azarenko O, Okouneva T, Singletary KW, Jordan MA and Wilson L: Suppression of microtubule dynamic instability and turnover in MCF7 breast cancer cells by sulforaphane. Carcinogenesis 29: 2360-2368, 2008.

2. Wall ME and Wani MC: Camptothecin and taxol: from discovery to clinic. J Ethnopharmacol 51: 239-253, 1996.

3. Huang MT, Smart RC, Wong CQ and Conney AH: Inhibitory effect of curcumin, chlorogenic acid, caffeic acid and ferulic acid on tumor promotion in mouse skin by 12-O-tetradecanoylphorbol-13-acetate. Cancer Res 48: 5941-5946, 1988.

4. Conney AH, Lysz T, Ferraro T, Abidi TF, Manchand PS, Laskin JD and Huang MT: Inhibitory effect of curcumin and some related dietary compounds on tumor promotion and arachidonic acid metabolism in mouse skin. Adv Enzyme Regul 31: 385-396, 1991.

5. Huang MT, Wang ZY, Georgiadis CA, Laskin JD and Conney AH: Inhibitory effects of curcumin on tumor initiation by benzo(a)pyrene and 7,12-dimethylbenz(a)anthracene. Carcinogenesis 13: 2183-2186, 1992.

6. Ishida H, Umino T, Tsuji K and Kosuge T: Studies on antihemorrhagic substances in herbs classified as hemostatics in Chinese medicine. VII. On the antihemorrhagic principle in Cirsium japonicum DC. Chem Pharm Bull 35: 861-864, 1987.

7. Park MK, Rhyu MR, Yoon BK, Kwon H, Jang S and Lee YJ: Modulation of the genomic estrogen receptor pathway by water extracts of Cirsium japonicum. Arch Pharm Res 31: 225-230, 2008 .

8. Kim EY, Jho HK, Kim DI and Rhyu MR: Cirsium japonicum elicits endothelium-dependent relaxation via histamine $\mathrm{H}(1)$ receptor in rat thoracic aorta. J Ethnopharmacol 116: 223-227, 2008.

9. Liu S, Luo X, Li D, Zahng J, Qiu D, She L and Yang Z: Tumor inhibition and improved immunity in mice treated with flavone from Cirsium japonicum DC. Int Immuonopharmacol 6: 1387-1393, 2006.

10. Liu S, Zhang J, Li D, Liu W, Luo X, Zhang R, Li L and Zhao J: Anticancer activity and quantitative analysis of flavone of Cirsium japonicum DC. Nat Prod Res 21: 915-922, 2007.

11. Miyashita T and Reed JC: Tumor suppressor p53 is a direct transcriptional activator of the human bax gene. Cell 80: 293-299, 1995.

12. Levine AJ: p53, the cellular gatekeeper for growth and division. Cell 88: 323-331, 1997.

13. Das A, Tang KS, Gopalakrishnan S, Waring MJ and Tomasz M: Reactivity of guanine at $\mathrm{m} 5 \mathrm{CpG}$ steps in DNA: evidence for electronic effects transmitted through the base pairs. Chem Biol 6: 461-471, 1999.

14. Budihardjo I, Oliver $\mathrm{H}$, Lutter $\mathrm{M}$, Luo $\mathrm{X}$ and Wang $\mathrm{X}$ : Biochemical pathways of caspase activation during apoptosis. Annu Rev Cell Dev Biol 15: 269-290, 1999.
15. Lockshin RA and Zakeri Z: Apoptosis, autophagy and more. Int J Biochem Cell Biol 36: 2405-2419, 2004.

16. Yang S, Liu J, Thor AD and Yang X: Caspase expression profile and functional activity in a panel of breast cancer cell lines. Oncol Rep 17: 1229-1235, 2007.

17. Green DR and Kroemer G: The phathophysiology of mitochondrial cell death. Science 305: 626-629, 2004.

18. Hasenjager A, Gillissen B, Muller A, Normand G, Hemmati PG, Schuler M, Dorken B and Daniel PT: Smac induces cytochrome $\mathrm{c}$ release and apoptosis independently from $\mathrm{Bax} / \mathrm{Bcl}-\mathrm{x}(\mathrm{L})$ in a strictly caspase-3-dependent manner in human carcinoma cells. Oncogene 23: 4523-4535, 2004.

19. Orrenius S: Mitochondrial regulation of apoptotic cell death. Toxicol Lett 149: 19-23, 2004.

20. Kim R: Recent advances in understanding the cell death pathways activated by anticancer therapy. Cancer 103: 1551-1560, 2005.

21. Yang HL, Chen CS, Chang WH, Lu FJ, Lai YC, Chen CC, Hseu TH, Kuo CT and Hseu YC: Growth inhibition and induction of apoptosis in MCF-7 breast cancer cells by Antrodia camphorate. Cancer Lett 231: 215-227, 2006.

22. Shim HY, Park JH, Paik HD, Nah SY, Kim DS and Han YS: Acacetin-induced apoptosis of human breast cancer MCF-7 cells involves caspase cascade, mitochondria-mediated death signaling and SAPK/JNK1/2-c-Jun activation. Mol Cells 24: 95-104, 2007.

23. Decaudin D, Marzo I, Brenner C and Kroemer G: Mitochondria in chemotherapy-induced apoptosis: A prospective novel target of cancer therapy. Int J Oncol 12: 141-152, 1998.

24. Cosulich SC, Savory PJ and Clarke PR: Bcl-2 regulates amplification of caspase activation by cytochrome c. Curr Biol 9: 147-150, 1999

25. Moore JD, Rothwell NJ and Gibson RM: Involvement of caspases and calpains in cerebrocortical neuronal cell death is stimulus-dependent. Br J Pharmacol 135: 1066-1077, 2002.

26. Yuan J, Shaham S, Ledoux S, Ellis HM and Horvitz HR: The C. elegans cell death gene ced-3 encodes a protein similar to mammalian interleukin-1 beta-converting enzyme. Cell 75: 641-652, 1993.

27. Jo EH, Kim SH, Ra JC, Kim SR, Cho SD, Jung JW, Yang SR, Park JS, Hwang JW, Aruoma OI, Kim TY, Lee YS and Kang KS: Chemopreventive properties of the ethanol extract of chinese licorice (Glycyrrhiza uralensis) root: induction of apoptosis and G1 cell cycle arrest in MCF-7 human breast cancer cells. Cancer Lett 230: 239-247, 2005

28. Behrens P, Brinkmann U and Wellmann A: CSE1L/CAS: its role in proliferation and apoptosis. Apoptosis 8: 39-44, 2003.

29. Chibazakura T, McGrew SG, Cooper JA, Yoshikawa H and Roberts JM: Regulation of cyclin-dependent kinase activity during mitotic exit and maintenance of genome stability by $\mathrm{p} 21$, p27 and p107. Proc Natl Acad Sci USA 101: 4465-4470, 2004.

30. Diehl JA: Cycling to cancer with cyclin D1. Cancer Biol Ther 1: 226-231, 2002.

31. Kitagawa M, Higashi H, Jung HK, Suzuki-Takahashi I, Ikeda M, Tamai K, Kato J, Segawa K, Yoshida E, Nishimura S and Taya Y: The consensus motif for phosphorylation by cyclin D1-cdk4 is different from that for phosphorylation by cyclin A/E-cdk2. EMBO J 15: 7060-7069, 1996. 